\title{
Proceeding
}

Supplementary Issue: Autumn Conferences of Sports Science. Costa Blanca Sports Science Events, 2-3 November 2018.

Alicante, Spain

\section{Athlete's motivations from different regions of Portugal for the practice of athletics as a federated sport}

JOÃO SERRANO ${ }^{1}$, LUIS MARTINS², MARCO BATISTA', SAMUEL AA HONÓRIO1, PEDRO DUARTE MENDES MENDES ${ }^{1}$, JORGE SANTOS ${ }^{1}$, HELENA MESQUITA ${ }^{1}$, JOAO ROCHA ${ }^{1}$, PAULO SILVEIRA ${ }^{1}$, JOÃO PETRICA ${ }^{1}$

${ }^{1}$ SHERU (Sport, Health and Exercise Research Unit), Polytechnic Institute of Castelo Branco, Portugal

${ }^{2}$ Polytechnic Institute of Castelo Branco, Portugal

\section{ABSTRACT}

Introduction: Athletics is an important sport because it offers a determining basic preparation for other different sports (Sampaio, 2010). Objective: The purpose of this study was to determine the motivations that led athletes to practice athletics and to know if the fact that lived in different country regions influences these motivations. The participants were 184 federated athletes from 5 different zones of Portugal (Castelo Branco, Coimbra, Leiria, Santarém and Setúbal). Methodology: To understand the motivations that lead athletes to practice athletics, the questionnaire EMI-2 (Exercise Motivation Inventory version 2 of Markland and Hardy (1993), translated for the Portuguese population by Alves and Lourenço (2003) was applied and were collected during the national championship. For statistical purposes we used descriptive statistics, arithmetic mean, standard deviation and inferential statistics, with the application of One-Way Anova and Kruskal-Wallis tests. Results: The results showed that the Psychological and Physical Condition motives were the most valued, while the Health and Body Related motives were the least valued by the athletes belonging to the different regions. As for the results of the means, only statistically significant differences were found in the physical fitness motives, more valued by athletes from the regions of Setúbal and Santarém and less valued from the athletes of Coimbra e Castelo Branco. Conclusions: The conclusions showed some uniformity in the

Corresponding author. SHERU (Sport, Health and Exercise Research Unit), Instituto Politécnico de Castelo Branco, Castelo Branco, Portugal.

E-mail: j.serrano@ipcb.pt

Supplementary Issue: Autumn Conferences of Sports Science. Costa Blanca Sports Science Events, 2-3 November 2018. Alicante, Spain.

JOURNAL OF HUMAN SPORT \& EXERCISE ISSN 1988-5202

(c) Faculty of Education. University of Alicante.

doi:10.14198/jhse.2019.14.Proc1.04 
importance attributed to the reasons that led the athletes to choose athletics as a federated sports practice. Key words: Athletics; Motivation; Practice of sports activities.

\section{Cite this article as:}

Serrano, J., Martins, L., Batista, M., Honório, S., Mendes, P.D., Santos, J., Mesquita, H., Rocha, J., Silveira, P., \& Petrica, J. (2019). Athlete's motivations from different regions of Portugal for the practice of athletics as a federated sport. Journal of Human Sport and Exercise, 14(1proc), S30-S36. doi:https://doi.org/10.14198/ihse.2019.14.Proc1.04 


\section{INTRODUCTION}

Motivation in sport can be defined as being a "psychological variable that moves the individual towards the accomplishment, orientation, maintenance or abandonment of a physical activity or sport" (Dosil, 2008: 129). Motivation is essential for the choice or practice of any kind of physical or sports activity (Lutz, et al., 2012). The reason for this is that motivation gives rise to greater energy towards a type of behaviour, having a unique role in all contexts of the human being's life, of those who practice PA, since it is the main factor for realization (Weinberg \& Gould, 2007). The motivation arises according to Serpa (1990) linked to the behaviour of the individual, where he stresses the personality factors or social variables that act when someone accomplishes something by which they can be evaluated, when they are in competition with others or try to reach some level of excellence. Fonseca \& Maia (2000) agrees with the previous idea, considering the motivation as a determinate cause and conditioner of the degree of effectiveness. Exercise practitioners are expected to evaluate their strength, endurance, flexibility, body composition, appearance (...), particularly when physical subdomain is important for the practitioner's self-esteem (Moutão, 2005).

It should be noted that the same activity for different individuals may have a distinct source of motivation, that is, some may be intrinsically motivated and others extrinsically. There are people who practice sport for pleasure, while others do it for medals and as a source of recognition. In theory, intrinsic origin behaviours are more productive and time-consuming than when motivations are extrinsic. When people do not understand their actions as internally guided to feel guided, they tend to become more easily demotivated for sports, since they do not feel autonomous in their choice (Guimarães \& Boruchovitch, 2004). Vasconcelos (2006) refers to the motivations for the practice of physical activity (PA) and sports activity, affirms that in these days the importance attributed to these activities by society resembles others such as: freedom, education, equality, health and quality of life. People attach increasing importance to the movement, contradicting the idea that sport practice is inadvisable because it is associated with the disease (Blair, 2002). Sport and PA become an integral part of social life and are recommended as a means of counteracting the harmful effects of the industrialized society's way of life (Mota, 2001). We agree with Marivoet (2005) when he says that PA and the sport activity have been gaining practitioners by the increase in demand in the scope of leisure practices, but also because we have seen the recognition of the importance of sports competition. At the end of the 20th century and at the beginning of the 21st century, several authors (Zanon \& Rocha, 2000; Vasconcelos, 2006; Nascimento, 2010) referred to an exponential increase in the number of people involved in walking and jogging. These athletic activities contribute, according to the authors, to the release of daily stress, emotional, psychological, cognitive and personal training improvements and that is why they are increasingly sought after. The ease of practice was also a determining factor for the exponential increase of these activities, since they do not require great techniques in terms of execution and can be practiced by all people without requiring large investments, individually, and in different spaces. Bragada (sd) and Sampaio (2010) emphasize the importance of athletics specialties in another aspect, when they say that they form the basis for many other sports, playing a central role in athletes' physical development. In almost all the sports that are used of the locomotion. An analysis of the studies carried out in Portugal allowed us to note that many investigations have been carried out on the motivations for practicing sports activities, however, few studies have focused on athletics and we did not find any that compared the motivations for practice of the sport by athletes from different regions. This was the focus of our investigation, so we sought to know the reasons and motives that lead athletes from different regions of Portugal (Castelo Branco, Coimbra, Leiria, Santarém and Setúbal) to choose athletics' as their sport practice and analyse the differences in that choices. 


\section{MATERIALS AND METHODOLOGY}

\section{Objective}

The purpose of this study was to determine the motivations that led athletes to practice athletics and to know if the fact that living in different regions influences these motivations.

\section{Participants}

The number of participants consisted of 184 federated athletes from five regions of Portugal (Castelo Branco, Coimbra, Leiria, Santarém and Setúbal) aged between 17 and 34 years old, being most of them of the male gender and divided according to the values shown in table 1.

Table 1. Number of participants divided by region

\begin{tabular}{|c|c|c|}
\hline District & $\mathbf{N}$ & $\%$ \\
\hline Castelo Branco & 34 & $18.5 \%$ \\
\hline Coimbra & 22 & $12.0 \%$ \\
\hline Leiria & 54 & $29.3 \%$ \\
\hline Santarém & 62 & $33.7 \%$ \\
\hline Setúbal & 12 & $6.5 \%$ \\
\hline
\end{tabular}

\section{Instruments}

The instrument used was the questionnaire EMI-2 (Exercise Motivation Inventory version 2 of Markland and Hardy (1993), translated to Portugal by Alves and Lourenço (2003).) The used version consists of 51 items that correspond to 14 factors / subscales and which are grouped into 5 dimensions (Psychological Motivations, Interpersonal Motivations, Health Motivations, Body-related Reasons and Motivation of Physical Condition). According to Moutão (2005), EMI-2 results in a more valid instrument than the other existing questionnaires. The questionnaire was applied to the athletes during the Portuguese championships, and authorizations were asked to the technicians responsible for the teams / athletes and the questionnaire was fulfilled by the athletes individually and always in the presence of the investigator to clarify any doubts. After the data collection, it was organized and stored using the statistical software IBM - SPSS - Statistical Package for the Social Sciences, Data Editor version 23 for Windows. At the statistical level we used descriptive statistics, arithmetic mean, standard deviation, and inferential statistics. We started by verifying the sample distribution through the Kolmorogov-Smirnov and Shapiro-Wilk tests, which indicated that the statistical tests to be applied according to the results were the parametric test of Analysis of Variance (ANOVA) and the nonparametric test of Kruskal-Wallis. The level of significance used in the study was 0.05 (5\%).

\section{RESULTS}

About the reasons that led the athletes from different regions of Portugal to choose the athletics sport for their federated sport practice, we present the mean values (between 1 and 5) obtained in each of the dimensions that belong to the questionnaire.

The results by region indicates in all of them the Psychological and Physical Condition motives were the most valued (with a mean of more than 3.00), except for the athletes in Leiria. Those related to body and health were the least valued in all regions (below the average of 3.00). We then verified the differences between athletes from different regions considering each of the dimensions regarding the motivations for the practice of athletics (table 3). 
Table 2. Analysis of the dimensions by region (mean values)

\begin{tabular}{lccccc}
\hline \multicolumn{1}{c}{ Motives } & C. Branco & Coimbra & Leiria & Santarém & Setúbal \\
\hline Psychological & 3.67 & 3.64 & 3.39 & 3.67 & 3.71 \\
Interpersonal & 3.04 & 3.30 & 2.82 & 3.11 & 3.02 \\
Health & 2.07 & 2.23 & 2.35 & 2.38 & 2.68 \\
Related to body & 1.61 & 1.74 & 1.86 & 2.04 & 2.45 \\
Physical condition & 3.31 & 3.34 & 2.89 & 3.53 & 3.76 \\
\hline
\end{tabular}

Table 3. Dimensions comparisons by region

\begin{tabular}{|c|c|c|c|}
\hline Dimensions & District & Mean & Sig \\
\hline \multirow{5}{*}{ Psychological } & C. Branco & 3.67 & \multirow{5}{*}{0.341} \\
\hline & Coimbra & 3.64 & \\
\hline & Leiria & 3.39 & \\
\hline & Santarém & 3.67 & \\
\hline & Setúbal & 3.71 & \\
\hline \multirow{5}{*}{ Interpersonal } & C. Branco & 3.04 & \multirow{5}{*}{0.203} \\
\hline & Coimbra & 3.30 & \\
\hline & Leiria & 2.82 & \\
\hline & Santarém & 3.11 & \\
\hline & Setúbal & 3.02 & \\
\hline \multirow{5}{*}{ Health } & C. Branco & 2.07 & \multirow{5}{*}{$0.22 C$} \\
\hline & Coimbra & 2.23 & \\
\hline & Leiria & 2.35 & \\
\hline & Santarém & 2.38 & \\
\hline & Setúbal & 2.68 & \\
\hline \multirow{5}{*}{ Related to body } & C. Branco & 1.61 & \multirow{5}{*}{0.244} \\
\hline & Coimbra & 1.74 & \\
\hline & Leiria & 1.86 & \\
\hline & Santarém & 2.04 & \\
\hline & Setúbal & 2.45 & \\
\hline \multirow{5}{*}{ Physical condition } & C. Branco & 3.31 & \multirow{5}{*}{0.005} \\
\hline & Coimbra & 3.34 & \\
\hline & Leiria & 2.89 & \\
\hline & Santarém & 3.53 & \\
\hline & Setúbal & 3.76 & \\
\hline
\end{tabular}

The results show that athletes from Setúbal region were the ones that most valued the psychological reasons (3.71) and the athletes from Leiria who had the least value for these goals $(3,39)$. In terms of interpersonal motives, the athletes of Coimbra $(3,30)$ were the ones that most valued these goals and the athletes of Leiria $(2,89)$ those that less valued these ones. Regarding the health reasons, the athletes from Setúbal $(2,68)$ were the ones that most valued these goals and the athletes from Castelo Branco (2.07) those that less valued them. Regarding Body Reasons, it was the athletes from Setúbal $(2,45)$ those who valued these goals the most, and the athletes from Castelo Branco (1.61) who had the least value in these goals. Regarding the Motivations of Physical Condition were the athletes of Setúbal (3.76) those who valued these goals the most 
and the athletes of Leiria $(2,89)$ those that less valued these goals. Despite the differences found, they were only significant $(0.005)$ in the variable of physical condition reasons.

\section{DISCUSSION}

The results presented make sense once we are studying active athletes and because of this, it is natural an increase tendency of these factors by the good sensations that this sports practice brings to them, for feeling that physical exercise is invigorating, allows recharging energies, provides challenging sensations, accessing a sports career, strengthening the body, improving musculoskeletal capacity. For minor reasons, we also consider it normal that they are related to health and to the body because the study has active athletes who are normally healthy and have less concerns about issues of body aesthetics, medical advice, health prevention problems and weight loss or improved appearance. When comparing the different regions, the results are also not very different, showing that the most valued and less valued reasons are similar, showing only the reasons for Physical Condition with statistically significant differences, which reveals that in these reasons are the highest differences which led them to practice athletics as federated sport. When comparing the results of our study with others, we found that the studies developed with athletes or young people (Fonseca \& Maia, 2000; Fernandes, 2006) revealed motivations similar to ours, that is, they value the psychological and conditional motives such as: "doing exercise", "achieving a higher level of sport", "improving technical skills", "To be in good physical condition" (...). However, studies developed with adults who performed physical activity in gymnasiums (Moutão 2005, Correia 2014) have referred different motivations of ours, such as those related to health and with interpersonal motives, "staying healthy" and "revitalizing". We could also verify that reasons such as "social recognition" or "having prestige", are little valued in all the studies found.

\section{CONCLUSIONS}

The conclusions showed some homogeneity and similarity in the importance given to the reasons that led the athletes to choose athletics as a federated sport practice, the most valued by the athletes of all regions was the psychological motives and the reasons of physical condition. The motives less valued in all regions were the motives related to body and health reasons.

\section{REFERENCES}

Alves, J. \& Lourenço, A. (2003). Tradução e adaptação do questionário de motivação para o exercício. Desporto, Investigação e Ciência. 2, 3-23.

Blair, S. (2002). Prefácio. In Biddle, S. \& Mutrie, N. (Eds.) Phychology of Physical Activity:determinants, Well-being and interventions. Routledge. 14-15.

Bragada, J. (s/d). O Atletismo na Escola - Proposta programática para a abordagem dos lançamentos "leves". Horizonte - Revista de Educação Física e Desporto. Vol. XVII. n 99. Jun-Jul.

Correia, L. (2014). Motivação para a prática de exercício físico - Estudo dos motivos para a prática das atividades de fitness no concelho de Celorico da Beira. Dissertação de Mestrado em Ciências do Desporto - Especialidade de Desportos de Academia. Instituto Politécnico da Guarda.

Dosil, J. (2008). Psicologia de la Actividad Física y del Deporte (2a ed.). Madrid: McGraw Hill. https://doi.org/10.4272/978-84-9745-351-6

Fernandes, P. (2006). Corfebol. Um estudo sobre as Motivações dos Jovens entre os 15 anos e os 19 anos para a Prática Desportiva. Lisboa: Edições Universidade Lusófona. 
Fonseca, A. \& Maia, J. (2000). A Motivação dos Jovens para a Prática Desportiva Federada: Um estudo com atletas das regiões centro e norte de Portugal com as idades compreendidas entre os $10 \mathrm{e}$ os 18 anos. Lisboa: Centro de Estudos e Formação Desportiva, Ministério da Juventude e do Desporto.

Guimarães, S. \& Boruchovitch, E. (2004) O estilo motivacional do professor e a motivação intrínseca dos estudantes: uma perspectiva da teoria da autodeterminação. Psicologia: Reflexão e Crítica, 17(2), 143-150. https://doi.org/10.1590/S0102-79722004000200002

Hauer, A. (2011). Perfis motivacionais para diferentes tipos de atividades físicas. Dissertação de Mestrado em Exercício e Saúde: Universidade Técnica de Lisboa, Lisboa.

Lutz, C., Canes, R., Beuron, T. \& Grohmann, M. (2012) Fatores motivacionais extrínsecos para a profissão militar. Revista da UNIMEP, 10(1), 164-188. https://doi.org/10.15600/16795350/rau.v10n1p164-188

Marivoet, S. (2005). Prática desportiva nos estilos de vida dos Europeus: obstáculos e tendências. in Gomes, R. (org.) Os lugares do lazer. Lisboa: IDP, 39-53.

Markland, D. \& Hardy, L. (1993). The exercise motivations inventory: Preliminary development and validity of a measure of individuals' reasons for participation in regular physical exercise. Personality and Individual Differences, 15, 289-296. https://doi.org/10.1016/0191-8869(93)90219-S

Mota, J. (2001). Actividade Física e Lazer - Contextos actuais e ideias futuras. Revista Portuguesa de Ciências do Desporto, 1(1): 124-129. https://doi.org/10.5628/rpcd.01.01.124

Moutão, J. (2005). Motivação para a prática de exercício físico. Estudo dos Motivos para a prática de Atividades de Fitness em Ginásios. Dissertação de Mestrado em Psicologia do Desporto e Exercício. UTAD: Vila Real, Portugal.

Nascimento, M. (2010). Contribuições da inclusão do atletismo no currículo escolar do ensino fundamental. Ágora: Revista de divulgação científica, 17(2): 94-108.

Samulski, D. (2009). Psicologia do Desporto. Edição Revisada e Ampliada. 2 ed. São Paulo: Manole.

Sampaio, A. (2010). Atletismo na Escola:Realidade? Universidade Católica de Brasilia. Dissertação de Licenciatura em Educação Física. Brasília.

Serpa, S. (1990). O treinador como líder. Panorama actual da investigação. Lisboa: Ludens, 12 23-32.

Vasconcelos, J. (2006). A Prática Desportiva na Região do Vale do Sousa - Estudo sobre a oferta desportiva das Autarquias. Dissertação de Mestrado em Gestão Desportiva. Faculdade de Ciências do Desporto e de Educação, Porto.

Weinberg, R., \& Gould, D. (2007). Foundations of Sport and Exercise Psychology (4th ed.). Champaign, Illinois: Human Kinetics.

Zanon, S. \& Rocha Jr, I. C. (2000) Iniciação ao Atletismo: Um diagnóstico do processo de desenvolvimento motor em crianças. Santa Maria: Kinesis, 57-74.

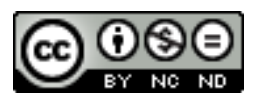

This work is licensed under a Attribution-NonCommercial-NoDerivatives 4.0 International (CC BY-NC-ND 4.0). 